\title{
PENYELESAIAN KREDIT BERMASALAH PADA PT. BANK NAGARI CABANG PARIAMAN
}

\author{
Anisa Desmayanti, Ratna Widayati \\ Akademi Keuangan dan Perbankan “pembangunan” Padang \\ anisadesmayanti2711@gmail.com
}

\begin{abstract}
This study aims to find out how to resolve non-performing loans at PT. Nagari Bank, Pariamaan Branch. Data taken from the results of interviews of authors and credit documentation data of PT. Nagari Bank Pariaman Branch. The results of this study are doubtful credit income with bad credit tends to increase from 2016 to 2019 and the highest non-performing loan income is in 2019. In this situation shows that the low level of education of the customer or debtor and credit management is less analysis of credit customers .
\end{abstract}

Keyword: Bad credit, Doubtful credit, Current credit, Substandard credit.

\section{PENDAHULUAN}

Lembaga perbankan merupakan salah satu instrument moneter yang tugas utamanya antara lain adalah memberikan kredit, selain memberikan jasa-jasa lainnya yang ada di bidang keuangan. Dalam pemberian kredit, antara bank satu dengan bank lainnya tidak sama baik dalam hal persyaratan maupun dalam prosedurnya.(Kasmir, 2014)

Menurut (Arnila, n.d.) Dalam perkembangan ekonomi sekarang ini kredit mempunyai peranan yang sangat penting untuk membantu masyarakat, yaitu untuk mengembangkan perekonomian masyarakat, dalam memperluas usaha ataupun mendirikan suatu proyek baru untuk memenuhi kebutuhan dan memperlancar kelangsungan kegiatannya masyarakayt.

Memperhatikan keberadaan perkembangan dan aktivitas bank, maka menjadi penting untuk mengetahui pengertian bank. Adapun pengertian bank dalam berbagai literatur sebagai berikut : Dalam Undang-Undang No.10 tahun 1998. Tentang Perbankan, yang merupakan perubahan dari Undang-Undang No.7 pasal 1 tahun 1992 tentang perbankan, disebut "Bank adalah badan usaha yang menghimpun dana dari masyarakat dalam bentuk simpanan dan menyalurkannya kepada masyarakat dalam bentuk kredit untuk meningkatkan taraf hidup rakyat banyak. (Kasmir, 2014)

Kredit bermasalah adalah ketidaksanggupan debitur untuk melunasi pimjamannya kepada bank berupa angsuran pokok dari pimjaman berserta bunganya, serta biaya lain dimana mengalami kegagalan karena deviasi (penyimpangan) sehingga tidak sesuai dengan perjanjian yang telah disepakati yang akhirnya dapat 
membawa kerugian kepada bank, untuk itu harus segera mungkin mendapatklan penyelesaian karena hal ini dapat merendahkan pendapatan bank

Pada pemberian kredit dapat terjadi kredit beresiko antara lain resiko operasional, dan resiko likuiditas oleh karena itu di dalam pemberian kredit bank melakukan prinsip kehati-hatian, agar dapat meminimalkan resiko tersebut. Dan bank menerapkan prinsip 5C dalam melakukan kredit yaitu character, capacity, capital, colleteral, dan condition. Dari kelima prinsip di atas collateral (jaminan) merupakan hal yang paling penting karena Setiap pengajuan kredit dari nasabah bank melakukan penganalisaan terhadap jaminan dari nasabah dan, apabila nasabah tidak dapat membayar maka barang jaminan dapat di lelang. Dalam penyaluran kredit kepada masyarakat tidak semua dana yang di salurkan kepada nasabah (kredit) dapat dikembalikan sebagai mana mestinya yang di sebut dengan kredit bermasalah.

Berdasarkan uraian diatas maka penulis tertarik untuk melakukan penyelesaian yang hasilnya akan dituangkan dalam laporan tugas akhir ", Penyelesaian Kredit Bermasalah Pada Pt. Bank Nagari Cabang Pariaman’,

Berdasarkan latar belakang tersebut, adapun rumusan masalah dalam penelitian ini yaitu 'Bagaimana cara penyelesaian kredit bermasalah pada PT. Bank Nagari Cabang Pariaman periode 2016-2019?'”

\section{METODE PENELITIAN}

Dalam pengumpulan data dan bahan untuk melakukan penelitian ini, penulis mengunkan metode dengan dua cara sebagai beriku : a. peninjauan langsung ke objek yaitu penelitian lagsung ke objek penelitian yang di pilih untuk meneliti hasil data primer. Penelitian waktu dan lapagan ini akan dapat membantu penulis untuk menambah data yang di perlukan. Adapun cara riset lapagan ini yaitu dengan cara mewawancarai langsung pihak terkaid dalam hal ini adalah perusahaan atau instansi terkaid. b. studi perpustakaan yaitu penelitian ini di lakukan ke perpustakaan berupa buku-buku ilmiah dan tulisan-tulisan yang berhubungan dengan pembahasan yang di lakukan.

\section{A. Pengertian Kredit}

Pengertian kredit menurut Undang-undang perbankan Nomor 10 pasal 1 ayat 11 tahun 1998 tentang perbankan adalah penyediaan uang atau tagihan yang dapat dipersamakan dengan itu, berdasarkan persetujuan atau kesepakatan pinjam- meminjam antara bank dengan pihak lain yang mewajibkan pihak peminjam melunasi utangnya setelah jangka waktu tertentu dengan pemberian bunga.(Sinugan, 1997)

Devinisi lain tentang kredit adalah penyediaan uang atau tagihantagihan yang dapat dipersamakan dengan itu berdasarkan persetujuan pinjam meminjam antara bank dengan pihak lain, yang mana pihak tersebut berkewajiban melunasi hutangnya setelah jangka waktu tertentu dengan jumlah bunga yang ditetapkan. Dalam lembaga-lembaga keuangan Islam kredit dikenal dengan pembiayaan, yang dimaksud dengan pembiayaan adalah penyediaan dana atau tagihan. 


\section{B. Fungsi Kredit}

a. Mencari keuntungan

Pertunjukan untuk memperoleh hasil dsri pemberian kredit tersebut. Hasil tersebut terutama dalam bentuk bunga yang di terima oleh bank sebagai balas jasa dan biaya administrasi kredit yang di bebankan kepada nasabah. Keuntungan ini penting untuk kelangsungan hidup bank. Jika bank yang terus menerus menderita kerugian, maka besar kemungkinan bank tersebut akan dilikuidasi atau di bubarkan.

b. Membantu usaha nasabah

Untuk membantu usaha yang membutuhkan dana. Baik dana untuk modal kerja maupun untuk kosumsi. Dengan hal tersebut, maka pihak debitur akan dapat mengembangkan dan memperluas usahanya.

c. Membantu pemerintah

Semakin banyak kredit yang di salurkan oleh pihak perbankan, maka semakin baik mengingat adanya peningkatan pembaguan di berbagai sektor. (Puspitasari, 2018)

Tujuan pemberian kredit adalah :

a. Keamanan (safety), prestasi yang diberikan dalam bentuk uang, barang atau jasa yang betul-betul terjamin pengembaliannya, sehingga keuntunganya yang di harapkan itu dapat menjadi kenyataan.

b. Keuangan ( profitability), merupakan tujuan dari pemberian kredit yang terjelma dalam bentuk bunga yang diterima.

\section{Tujuan kredit}

Dengan demikian tujuan kredit yang diberikan oleh suatu bank adalah :

a. Turut menyukseskan program pemerintah di bidang ekonomi dan pembagunan.

b. Meningkatkan aktifitas perusahaan agar dapat menjalankan yang berfungsi untuk menjamin kebutauhan masyarakat.

c. Memperoleh lama agar kelangsungan hidup perusahaan terjamin, dan dapat memperluar usahanya.

Keuntungan bagi pemerintah dengan menyebar pemberian kredit adalah :

a. Penerimaan pajak, dari keuntungan yang di peroleh nasabah dan bank.

b. Meningkatkan barang dan jasa, dan hal ini dapat kita lihat dalam peningkatan jumlah barang dan jasa yang beredar di masyarakat.. 


\section{Pengertian kredit Bermasalah}

Kredit bermasalah merupakan kredit yang telah di salurkan oleh Bank, dan nasabah tidak dapat melakukan pembayaran atau melakukan angsuran sesuai dengan perjanjian yang telah di tandatagani oleh Bank dan nasabah. Penilaian atas pengolongan kredit baik kredit tidak bermasaklah maupun kredit bermasalah tersebut di lakukan secara kuantitatif,maupun kualitatif. Penilaian secara kuantitatif dilihat dari kemampuan debitur dalam melakukan pembayaran angsuran kredit,baik angsuran pokok pinjaman ataupun bunga. Adapun penilain kredit secara kualitatif dapat di lihat dari prospek usaha dan kondisi keuangan debitur. Kredit bermasalah akan berakibat pada kerugian bank, yaitu kerugian karena tidak diterimanya kembali dana yang telah disalurkan, maupun pendapatan bunga yang tidak dapat di terima. Artinya, bank kehilangan kesempatan mendapat bunga, yang berakibat pada penurunan secara total.

\section{Tabel 1 \\ KOLEKTIBILITAS KREDIT BANK NAGARI CABANG PARIAMAN \\ (Dalam Juta Rupiah)}

\begin{tabular}{|c|l|c|c|c|c|c|c|c|c|}
\hline No & Jenis kredit & $\mathbf{2 0 1 6}$ & $\mathbf{\%}$ & $\mathbf{2 0 1 7}$ & $\mathbf{\%}$ & $\mathbf{2 0 1 8}$ & $\mathbf{\%}$ & $\mathbf{2 0 1 9}$ & $\%$ \\
\hline 1 & Lancar & 39,101 & $70.86 \%$ & 53,613 & $75.77 \%$ & 62,249 & $77.77 \%$ & 79,479 & $82.21 \%$ \\
\hline 2 & $\begin{array}{l}\text { Kurang } \\
\text { lancar }\end{array}$ & 124 & $0.22 \%$ & 27 & $0.04 \%$ & 100 & $0.12 \%$ & 198 & $020 \%$ \\
\hline 3 & Diragukan & 790. & $1.43 \%$ & - & $0.00 \%$ & 52 & $0.06 \%$ & 154 & $016 \%$ \\
\hline 4 & Macet & 15,169 & $27.49 \%$ & 17,120 & $24.19 \%$ & 17.645 & $22.04 \%$ & 16,847 & $1743 \%$ \\
\hline & Jumlah & 55.184 & $100.00 \%$ & 70,760 & $100.00 \%$ & 80,046 & $100.00 \%$ & 96,678 & $100.00 \%$ \\
\hline & NPL & 16,083 & $29.14 \%$ & 17,147 & $24.23 \%$ & 17,797 & $22.23 \%$ & 17,199 & $17.79 \%$ \\
\hline
\end{tabular}

Sumber : Pt.Bank Nagari Cabang Pariaman, 2019

Dari tabel di atas dapat dilihat pendapatan kredit lancar pada tahu 2016 senilai 39,101 atau sama dengan $70.86 \%$, sedangkan pada tahun 2017 pendapatan kredit lancar sebesar 53,613 dalam bentuk \% sebesar $75.77 \%$, dan pendapatan pada tahun 2018 sebesar 62,249 sama dengan $77.77 \%$, sedangkan pada tahu 2019 mengalami kenaikan sebesar 79,479 sama dengan $82,21 \%$, sedangkan pendapatan kredit kurang lancar pada tahun 2016 sebesar 124. sama dengan $0.22 \%$, dan tahun 2017, sebesar 27 sama dengan $0.04 \%$, sehingga pendapatan pada tahun 2018 mengalami kanaikan sebesar 100. dalam \% sebesar $0.12 \%$, dan pada tahun 2019 mengalami kenaikan lagi 
sebesar 198 sama dengan $0.20 \%$. dan pendapatan kredit di ragukan pada tahun 2016 sebesar 790 sama dengan $1.43 \%$, sedangkan pada tahun 2017 pendapatan kredit yang di ragukan nihil, pada tahun 2018 pendapatan kredit yang di ragukan naik sebesar 52 atau sama $0.06 \%$, setelah itu mengalami kenaikan lagi pada tahun 2019 sebesar 154 dalam \% 0.16. sedangkan pendapatan kredit macet dari tahun 2016 sebesar 15,169 sama dengan 27.49\%, dan pada tahun 2017 24,19\%, sedangkan pada tahun 2018 sebesar $22.04 \%$, dan mengalami kenaikan lagi pada tahun 2019 sebesar $17.43 \%$.

Dengan keterangan di atas dapat disimpulkan bahwa total dari pendapatan kredit lancar, kurang lancar, diragukan dan macet mengalami peningkatan dari tahun ke tahun baik dari penjumlahan maupun dari persennya.

\section{Penyebab Terjadinya Kredit Bermasalah}

a. Karena kesalahan bank

1) Kurang pengecekan terhadap latar belakang calon nasabah.

2) Kurang tajam dalam menganalisis terhadap maksud dan tujuan pengunaan kredit dan sumber pembayaran kredit.

3) Kurang pemahaman terhadap kebutuhan keuangan yang sebenarnya dari calon nasabah dan manfaat kredit yang diberikan.

4) Kurang mahir dalam menganalisis laporan keuangan calon nasabah

5) Kurang lengkap mencantumkan syarat-syarat.

6) Terlalu agresif.

7) Pemberian kelonggaran terlalu banyak.

8) Kurangnya pengalaman dari penjabat kredit.

9) Pejabat kredit mudah dipengaruhi, diintimidasi atau dipaksa oleh calon nasabah.

10) Kurang melakukan kontak dengan nasabah.

b. Karena kesalahan nasabah.

1) Nasabah tidak berkomitmen.

2) Nasabah tidak mempunyai pengalaman.

3) Nasabah tidak memberikan waktu untuk usahanya.

4) Nasabah tidak jujur.

5) Nasabah serakah.

Gejala yang menyebabkan timbulnya kredit bermasalah :

a. Ada tunggakan.

b. Mengajukan perpanjangan.

c. Kondisi keuangan menurun.

d. Hubungan dengan bank menjadi renggang, menghindar setiap kali dihubungi.

e. Penggunaan kredit tidak sesuai dengan rencana. 


\section{Tindakan Peyelamatan Kredit Bermasalah}

Pada saat bank telah memutuskan untuk melakukan tindakan penyelamatan kredit bermasalah maka hal ini tergantung dari kesulitan yang dihadapi oleh nasabah. Maka tindakan yang dapat diambil melalui lima cara sebagai berikut :

a. Rescheduling

Suatu usaha penyelamatan kredit dengan cara memperpanjang jangka waktu kelunasan atau perubahan besarnya angsuran pada setiap periode.tindakan ini dapat diberikan jika :

1) Masalah yang dihadapi hanya kesulitan likuiditas sementara.

2) Debitur bersikap kooperatif atau jujur.

3) Menajemen dan sarana produksi berjalan baik.

4) Prospek usaha dapat diharapkan.

5) Penyelamatan lebih baik daripada likuidasi.

b. Reconditioning

Suatu usaha untuk memungkinkan pengembalian hutang oleh debitur dengan cara memberikan keringanan berupa perubahan syarat-syarat, seperti penyesuaian suku bunga. Dalam hal ini tindakan yang diberikan berupa keringanan atau perubahan persyaratan kredi, sebagai berikut :

1) Kapitalisasi bunga, bunga yang dijadikan utang pokok sehingga nasabah dalam waktu tertentu tidak perlu membayar bunga, tetapi hutang pokoknya dapat melebihi plafon yang disetujui. Cara ini ditempuh dalam hal prospek usaha nasabah baik.

2) Penundaan pembayaran bunga, bunga tetap dihitung, tetapi penagihan atau pembebananya pada nasabah tidak dilaksanakan sampai nasabah mempunyai kesanggupan. Berdasarkan bunga yang terhutang tidak dikenakan bunga dan tidak menambah plafon kredit.

3) Penurunan suku bunga, dalam hal nasabah dinilai masih mampu membayar bunga pada waktunya, tetapi suku bunga yang dikenakan terlalu tinggi untuk tingkat aktivitas dan hasil usaha pada waktu itu. Cara ini jalankan jika hasil operasi nasabah memang menunjukan surpluf/laba dan likuiditas memungkinkan untuk membayar bunga.

4) Pembebasan bunga, dalam hal tersebut nasabah memang dinilai tidak sanggup membayar bunga karena usaha nasabah hanya mencapai pulang pokok.

5) Pengkonversasian, disebut dengan kredit jangka pendek menjadi kredit yang jangka panjang dengan syarat yang lebih ringan. 
c. Restructuring

Alternatife penyehatan kredit dengan cara menambah modal nasabah dan pertimbangan nasabah memang memutuhkan tambahan dana dan usaha yang dibiayai memang masih layak. Tindakan ini dapat dilakukan dengan cara :

1) Tambahan kredit

Apabila nasabah kekurangan modal kerja, maka perlu dipertimbangkan penanaman modal kerja dan juga dalam hal investasi, baik perluasan maupun tambahan investasi.

2) Tambahn modal

Apabila tambahan kredit memberatkan nasabah, sehubungan dengan pembayaran bunganya, maka perlu dipertimbangkan tambahan modal sendiri.

d. Kombinasi

Merupakan kombinasi dari ketiga jenis yang diatas. Seseorang nasabah dapat saja diselamatkan dengan kombinasi antara rescheduling dengan restructuring, misalnya jangka waktu diperpanjang pembayaran bunga ditunda atau reconditioning dengan rescheduling misalnya jangka waktu diperpanjang modal di tambah.

1. Penyitaan jaminan

Merupakan jalan terakhir apabila nasabah benar-benar sudah tidak punya itikad baik ataupun sudah tidak mampu lagi untuk membayar semua hutang-hutangnya.

Dari uraian di atas disimpulkan bahwa factor utama yang menjadi pertimbangan dalam upaya penyehatan kredit bermasalah adalah karakter manejemen atau prospek usaha. Debitur bermasalah memungkinkan disehatkan apabila manejemennya terbuka dan memiliki rencana usaha yang jelas. Dalam pelaksanaan penyehatan kredit seringkali bank harus memberikan keringanan seperti suku bunga yang lebih rendah dari suku bunga komersial.

Pihak bank kurang menyetujui cara pemberian keringanan berupa penurunan suku bunga, namun bagaimanapun juga masih lebih baik penerimaan pendapatan bunga yang lebih kecil daripada tidak sama sekali. Misalnya sekarang bagaimana mengimbangi pemberian keringanan tersebut.

Untuk memperlancar proses pengarapan penyelamatan kredit bermasalah diperlukan suatu strategi khusus dalam melakukan negosiasi dengan debitur agar tercapai hasil yang maksimal. 


\section{Pembahasan}

\section{a. Cara Penyelesaiannya}

Secara umum dalam pemberian kredit banyak menghadapi berbagai hambatan, yang terdiri dari hambatan intern dan ekstrn yang mengakibatkan terjadinya kredit bermasalah. Hambatan intern merupakan hambatan yang timbul dari pihak bank seperti sebagai berikut :

a. Kurangnya pengecekan terhadap latar belakang calon nasabah

b. Kurang tajam dalam menganalisis terhadap maksud dan tujuan penggunaan kredit dan sumber pembayaran kembali.

c. Kurang pemahaman terhadap kebutuhan keuangan yang sebenarnya dari calon nasabah dan manfaat kredit yang diberikan.

d. Kurang mahir dalam menganalisis laporan keuangan calon nasabah.

e. Kurang lengkap mencantumkan syarat-syarat.

f. Pemberian kelonggaran terlalu banyak.

g. Kurang pengalaman dan pejabat kredit.

h. Pejabat kredit mudah dipengaruhi, diintimidasi atau dipaksa oleh calon nasabah.

Hambatan ekstern merupakan hambatan yang timbul dari pihak nasabah :

a. Merosotnya perekonomian debitur

b. Terjadinya PHK mendadak ditempat kerja debitur

c. Usaha debitur tutup

d. Penurunan omset usaha debitur

e. Terjadinya konflik keluarga (Bercerai)

Dalam hal ini dapat disimpulkan penyelesaian kredit bermasalah pada PT. bank nagari cabang Pariaman sebagai berikut :

a. Melakukan peringatan dini yang merupakan serangkaian sistem yang dilakukan untuk pemberitahuan akan terjadinya kredit bermasalah di sengaja maupun tidak disegaja oleh nasabah.

b. Penagihan merupakan suatu hal yang di lakukan oleh pihak bank kepada nasabah tentang penagung jawabban terhadap kredit macetnya atau hal yang membuat kreditnya bermasalah.

c. Restrukturisasi kredit adalah upaya perbaikan yang di lakukan dalam kegiatan perkreditan terhadap debitur yang berpotensi yang mengalami kesulitan untuk kewajibannya. Kebijakan restrukturisasi kredit yang dilakukan pihak bank antara lain yaitu :

1). Penurunan suku bunga kredit

2). Perpanjangan jangka waktu kredit

3). Pengurangan tunggakan bunga kredit

4). Pengurangan pokok tindakan kredit

d. Penyerahan kredit bermasalah pada pihak ketiga merupakan hal yang di laporkan oleh pihak bank kepada pihak yang berwajib mengenai keadaan atau prilaku tidak bertagung jawab oleh pihak nasabah. 
e. Pelelangan kredit bermasalah melalui lelang agunan seperti melelang tanah, rumah, dan kendaraan.

f. Pemberian keringanan pembayaran tunggakan bunga dan denda.

\section{Simpulan}

1. Kredit bermasalah yang terdiri dari kredit kurang lancar, kredit diragukan dan kredit macet cenderung mengalami kenaikan sejak tahun 2016 sampai 2019. Kredit bermasalah tertinggi berada pada tahun 2019 terdapat pada pendapatan kredit diragukan, keadaan ini menunjukkan manajemen kredit kurang melakukan penganalisaan terhadap nasabah kredit.

2. Untuk memberikan keamanan dalam pemberian kredit nasabah maka bank nagari cabang pariaman meminta adanya jaminan untuk kredit kepada calon nasabah.

3. Penyehatan dalam kredit bermasalah yang dilakukan oleh bank nagari cabang pariaman dapat dilakukan dengan kombinasi atau dengan cara memberi surat tunggakan atau peringatan kepada pihak debitur dan memberikan keringan pemberian bunga atau tunggakan pokok.

4. Penyebab dari permasalahan kredit dikarenakan terdapat kesalahan dari pihak bank yang kurang teliti dalam menganalisa dari keterangan calon nasabah sehingga dari maksud dan tujuanya beserta sumbernya untuk mengembalikan kredit yang di cairkan tidak dapat diketahui secara jelas, rendahnya tingat pendidikan dari nasabah atau debitur yang menerima kredit serta jarangnya komonikasi yang terbuka antara pihak bank dengan sicalon nasabah hal ini dapat mengakibatkan kredit bermasalah.

\section{UCAPAN TERIMA KASIH}

Terimakasih penulis sampaikan kepada :

1. Kepada kedua orang tua yang selalu memberikan dukungan baik secara moril maupun materil.

2. Direktur AKBP peserta prodi AKBP yang telah memberikan kesempatan kepada penulis untuk melakukan penelitian ini.

3. Dosen pembimbing yang telah memberikan arahan dan bimbingan hingga tugas akhir ini bias diselesaikan.

4. Pimpinan PT. Bank Nagari Cabang Pariaman yang telah mengizinkan penulis dalam memperoleh informasi beserta pengambilan data.

5. Semua pihak yang telah memberikan dukungan dan bantuanya dalam penyelesaian tugas akhir ini. 


\section{DAFTAR PUSTAKA}

Arnila, S. (n.d.). Sistim pengendalian kredit untuk mempertahankan likuiditas pada pt. bank nagari cabang painan . 1-13.

Amelia, L., \& Marlius, D. (2018). Pengendalian Kredit Dalam Upaya Menciptakan Bank Yang Sehat Pada PT. Bank Pembangunan Daerah Sumatera Barat Cabang Utama Padang. https://doi.org/10.31227/osf.io/kpc64

Alanshari, F., \& Marlius, D. (2018). Prosedur Pemberian Kredit KPR Pada PT. Bank Tabungan Negara (Persero) TBK Cabang Pembantu Bukittinggi. https://doi.org/10.31227/osf.io/rsfhc

Baiya, \& Fernos, J. (2019). Analisis Faktor-Faktor Penyebab Kredit Macet Pada Bank Nagari Cabang Siteba. https://doi.org/10.31227/osf.io/4xuks

Firmansyah, A., \& Fernos, J. (2019). Analisis Kredit Bermasalah Dilihat Dari Standar Non Performing Loan (NPL) Pada PT. Bank Perkreditan Rakyat (BPR) Prima Mulia Anugrah Cabang Padang. https://doi.org/10.31227/osf.io/gcj94

Febriansyah, I. (2019). Penyelesaian Kredit Bermasalah PT. Bank Pembangunan Daerah (BPD) Sumbar Cabang Alahan Panjang Kabupaten Solok Ilham Febriansyah, Afriyeni. Akademi Keuangan Dan Perbankan, 1-14. https://osf.io/preprints/vutmj/

Ikbal, M., \& Marlius, D. (2017). Pengaruh Jumlah Taksiran Dan Uang Pinjaman Terhadap Laba Bersih Pada PT. Pegadaian (UPC) Gurun Laweh. https://doi.org/10.31227/osf.io/uch4a

Kasmir, D. (2014). Bank Dan Lembaga Keuangan Lainnya. Edisi Revisi 2014 PT Raja Grafindo Persada Jakarta.

Puspitasari, R. (2018). Sebagai salah satu syarat untuk memperoleh gelar Ahli Madya pada Program Studi Keuangan dan Perbankan Sekola Tinggi Ilmu Ekonomi Kesatuan. July. https://doi.org/10.13140/RG.2.2.10882.99522

Sinugan, M. (1997). Menejemen Dana Bank (p. 317). PT. Bumi Aksara, Jakarta.

Widayati, R. (2019). Penyelesaian Kredit Bermasalah Pada PT. Bank Perkreditan Rakyat (BPR) Nagari Kasang. https://doi.org/10.17605/OSF.IO/D4MF3

Widayati, R. (2019). Pelaksanaan Prinsip Kehati-Hatian Dalam Pemberian Kredit Konsumtif Pada Bank Nagari Cabang Siteba. https://doi.org/10.17605/OSF.IO/FZVXR

Widayati, R. (2019). Aktivitas Pemberian Kredit Komersil Pada Bank Nagari Cabang Sijunjung. https://doi.org/10.17605/OSF.IO/QTVZ9

Widayati, R. (2019). Pelaksanaan Kredit Pada Bank Perkreditan Rakyat LPN Pasar Baru Durian Sawahlunto. https://doi.org/10.17605/OSF.IO/5HPAB

Widayati, R. (2019). Upaya Penanganan Kredit Bermasalah Pada Bank Nagari Cabang Utama Padang. https://doi.org/10.17605/OSF.IO/YJ3KN 
Widayati, R. (2019). Aktivitas Pemberian Kredit Usaha Pada PT. Bank Perkreditan Rakyat Batang Kapas. https://doi.org/10.17605/OSF.IO/EDPN4 